\title{
Mission to live: A gendered perspective on the experience of migration in Southern Africa
}

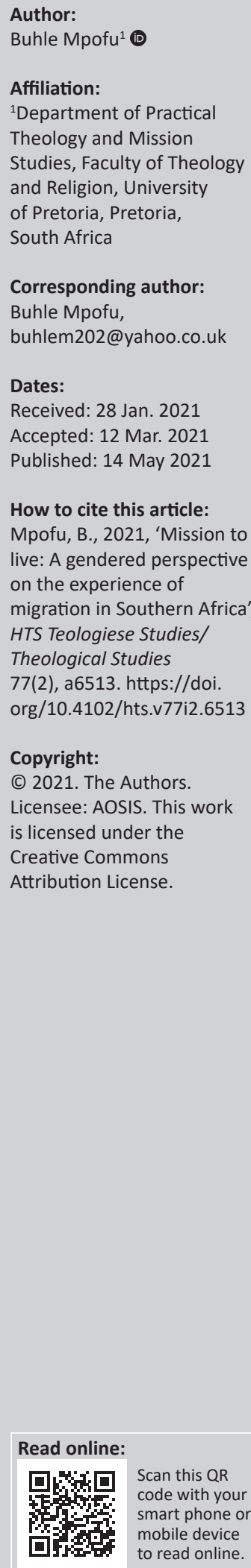

Extensive work has been carried out on gender and social transformation but there is a need for more work between these intersecting trajectories and their implications for Christian mission. Drawing on data collected from one of the migrants this current study employs the postcolonial lens to analyse interview responses on a migration experience of a young female migrant in South Africa and highlights survival strategies for young migrants by demonstrating that the impact of changing global socio-economic landscapes and poverty on migrant communities presents opportunity to explore alternative missional paradigms and theologies that address conditions of deprivation. As a contribution to United Nations (UN) Sustainable Development Goals, this study also highlights how some migrant women use situations of deprivation to promote socio-economic transformation through radical doctrines of resistance. Interrogating key themes that emerged from the interview (2) alongside Dolores William's doctrines of resistance demonstrates how one adolescent migrant embodies the radical doctrine of hope as lived reality expressed through a resilient theology of survival, which is sustained by developing and adapting to new lifestyles through cultural capital, skills, competency, new personal qualities, fashion and language or accents as means for survival strategies in the face of hostility.

Contribution: By reflecting on the complex and gendered survival strategies for migrant women in religious communities, this article represents a systematic and practical reflection within a paradigm in which the intersection of Philosophy, Religious Studies, Social Sciences, Humanities and Natural Sciences generates an interdisciplinary, multidisciplinary and trans disciplinary contested discourse.

Keywords: deprivation; doctrines of resistance; gender; migration; survival strategies; South Africa.

\section{Introduction}

It is important to state from the onset that data analysed in this contribution are not a representative sample for all young women migrants but present an opportunity for alternative narratives in gendered migration discourses, and this example should not be treated as a representative sample in any way. Young migrant women are often vulnerable to and at risk of economic, sexual and other forms of exploitation. Therefore, the complexity of the circumstances of migrant women and young girls demands that we pay attention to their needs in line with the United Nations (UN) Sustainable Development Goals (SDGs): (1) 'End poverty in all its forms everywhere' and (2) 'Achieve gender equality and empower women and girls' (UN:_18). When people are in desperate situations of need, they are often prone to adopting reckless strategies as a means to address their problems. It has been observed that situations of deprivation -whether because of poverty, war, famine or other calamitous causes -are the endemic instigators of actions of surprising dimensions (Tushima 2018:1). Müller (2011:1) has asked the question, 'in what sense is our time a time of transition?', noting that 'Different words, concepts and metaphors are used to describe the transition we experience ... and Different scholars prefer different expressions to describe the transition' (Müller 2011:1).

Transitions happen in different ways and for Christian communities there are different concepts and metaphors that describe this transition from the perspective of God's agency. This is the reason the World Council of Churches (WCCs) recognises the Spirit of Mission as the 'Breath of Life' (ed. Keum 2013:7), Spirit of Liberation as 'Mission from the Margins' (p. 14) and Spirit of Community as reflected in 'Church on the Move' (p. 21). Some positive experiences of the 'Church on the Move' are evident in the experiences of Christian African migrant women in South Africa.

Note: Special Collection: Women Theologies, sub-edited by Sinenhlanhla S. Chisale (Midlands State University) and Tanya van Wyk (University of Pretoria). 
Some of these experiences are discussed in this contribution to demonstrate that there are people who use 'situations of deprivation' to promote a radical doctrine of hope expressed through a pastoral theology of resistance and resilience.

Although not exhaustive, the first section presents literature that deals with some important aspects of gender and social transformation to demonstrate how these intersections impact social transformation and highlight how gender stereotyping remains entrenched in society in spite of commendable progress made through legal, cultural and intellectual engagement that has questioned gender discrimination in many forms(Smith 2014:1). In my previous research I delved deeper into migration narratives (Mpofu 2018a, 2019a, 2019b) and demonstrated how the interface of religion and migration plays out in socio-economic transformation. There are scholars who have observed that the relationship between religion and social transformation in Africa; and the religiosity of some South African communities, provides evidence, which 'demonstrates that the Christian religion can promote social transformation' (Erasmus 2005:1)in addressing gender inequality in church and society. It has also been clearly articulated that 'religion constitutes an inextricable part of African society as political and socio-economic activities are often flavoured with religious expressions and rituals' (Agbiji \& Swart 2015:1). Therefore, there is a need for ongoing exploration of gender dimensions with regard to church's missional engagement with experiences of female migrantsand how they are responding to deprivation and threatening circumstances.

Whilst exploring the changing dynamics and characteristics of being a church today, Pillay (2017:1) observed that the church has to be a transformation and change agent and established that 'it is not so much about what the church believes, but in what it does that matters most in this day and age'. The report of the International Association for Mission Studies (IAMS) (2012:2) shows that one of the strongest 'themes that emerged during the conference - was the strong link between the biblical narrative and the narratives and dramas of present-day migration'. Although expressed in subtle and dramatic narratives, migration experiences reflect the creative engagement of biblical discourse with migrant experiences. These encounters enrich social transformation and it can be argued that it is not so much about what the Christians believe, but it is about what Christians do in the face of deprivation that matters. It is for this reason that Tushima (2018) explored Genesis 12:10-13:2 to unveil what he labelled as the 'dissimulations of Abram' because he manipulated his wife, Sarai, into thinking that her beauty posed a threat to him. Tushima (2018) contends that Abraham's primary motive was the pursuit of economic gain in the face of the severe famine that had impoverished him in Canaan. As Tushima (2018) further observed:

[A]bram also succeeded in making Pharaoh believe that Sarai was his sister, on which account he exchanged her for material again. This analysis affords insight into the insecurity, anxiety, feelings of alterity of immigrant populations in their liminal conditions, the mistrust of immigrants by the state and host communities, and the ensuing power play (including sexual politics and/or commerce) with its concomitant perils. Through these, the passage speaks anew to contemporary communities of faith in view of the prevalent and ever-increasing migratory trends of the 21st century. (p. 1)

There is a need for more insight to shed light into what constitutes insecurity, anxiety or feelings of alterity amongst immigrant populations in their liminal conditions, which are often characterised by mistrust from the state and host communities (Tushima 2018:1). With the changing global socio-economic landscapes and the dire consequences of poverty on migrant communities, which has been exacerbated by coronavirus disease 2019 (COVID-19), consequently there is a need to explore alternative missional paradigms that not only place the plight of the marginalised at the centre of mission (Mpofu 2020b) but also develop theologies that address conditions of deprivation and in particular the gender dimensions of displacement as a means to address some failures of government to deal decisively with communities and leaders who exploit the poor (Mpofu 2020a). From another perspective, there are emerging theologies of resistance, which creatively engage liminal conditions of deprivation. These theologies of migration are motivated by faith communities' pursuit of a moral and social responsibility through promoting hospitable reception and integration of migrants who often have to rely on transnational ties and citizenship to navigate survival strategies in both home and host communities (Parekh 2000 cited in Kostakopoulou 2003):

$[T]$ ransnational citizenship denies neither the existence nor the relevance of borders and nation-states. It pays attention to nonstate networks and communities formed beyond the state and recognises that belonging is no longer exclusive in the sense that an individual should belong to one and only one state. It can be both multiple and partial. Multicultural citizenship, on the other hand, is sensitive to the differentiated character of plural 'magalopoleis' that are characterised by the incessant traffic of people back and forth. It aims at pluralising the nation and making ethnic migrant communities an integral part of a changing nation rather than going beyond it. (p. 87)

In the context of transnational citizenship, theologies of migration reflect concerns for new ways with regard to responses of the church in the context of increasing visible migrant communities in host countries, and the inadequacy of state responses to the needs of migrants and refugees who are often vulnerable in the face of hostility from local communities. By challenging state interventions or lack of interventions therein, these theologically oriented responses draw from a range of themes such as care or hospitality (eds. Groody \& Campesse 2008), church as safe nets for hosting migrants and refugees(Cruz 2010; Mpofu 2015, 2018), church as suffering body (Rivera 2012) and theologies of belonging and identity (Mpofu 2019). Gender is a product of intersecting trajectories of socialisation such as race, class, ethnicity and nationality, and it is important that these constructions must be recognised as contextually constituted, fluid and wide ranging given the historical and geographical differentiation (Connell 1997; Laurie, Holloway \& Smith 1999). By extension, the creation of colonial borders to which citizenship and religion contribute 
is a major factor in the process of naturalising nationality and gender identity. Therefore, there is a need for closer examination of femininity and masculinity within the broader discourse of socio-economic development. How do gender and religion impact the experiences of migration and what is the role of Christian mission?

Scholars focusing on theologies of migration have tended to explore two distinct areas: firstly, the instrumental use of religion during and after migration as demonstrated in the work of Adogame (2010) and Levitt (2007); secondly, theologies of migration that draw from identity politics themes, which are evident in the works of Adogame and Spikard (2010). The research by the latter primarily deals with uses of religion as a resource during migration. There are also scholars whose studies explore how new migrants use religious sites as the primary site for building social networks and approach religion as a source of resilience to navigate migration challenges (Hagan \& Ebaugh 2003). Other scholars have creatively engaged the means by which migrant communities replicate religious practice sand symbols at various sites of settlement as an assertion of their cultural and religious identity (Levitt 2007).

Scholars in gender also suggest that social identities are a vehicle through which individuals are socialised and naturalised into their local contexts and gender roles develop as roles are ascribed through 'gender identity', which designates them as male or female (Laurie et al. 1999:3) or even 'transnational identities' (Levitt 2007). The naturalisation of gender identities draws from biological differences wherein femininity, for example, assumes motherhood as nurturing and attributes the desire for pretty clothes and the exhibition of emotions as feminine (Laurie et al. 1999:3). A gendered perspective of citizenship is undergirded by an assertion that upholds the rights of women and advocates equal treatment across genders. In essence, the extent to which individuals understand and subscribe to prescribed gender roles is dependent on their context. It is for this reason that Hooks (2004) concluded that factors such as class, race, citizenship and ethnicity determine how individuals construct their gender identities (Hooks 2004).

Bringing the intersections of gender and migration into the experiences of women migrants, Williams (1993) reflected on survival strategies for black women through what she labels womanist God-talk and articulates what she calls 'doctrines of resistance' in a gender sensitive theology, which recognise the agency of women and how they survive the threats to their well-being. As a womanist theology, this approach transforms traditional practices through scriptural and biblical interpretations to empower women. Therefore, her theology interrogates the social constructions of black womanhood and assumes a liberating perspective towards life-giving narratives and excavating the life stories of women in the church through the lens of migration experiences, which take seriously the experiences and 'languages' of black women (Mitchem 2002) and interrogating social constructions by excavating life stories for women. This is the underlying assumption on the use of Williams' 'doctrines' of resistance, which we hope to employ in shedding some light on how contemporary migrant women resist xenophobia through articulations, which generate and sustain hope for survival in a hostile context.

Scholarly research in gender has evolved with an interest on gender identity expanding to include identities such as queer, lesbian, gay, bisexual and transgender (LGBT) as evidenced in the work of Butler (1990) and Messner (1992) as some observe that 'natural' masculinity mayincorporate fatherhood or what it means to act 'tough', as in stimulating a desire for sports and competition or hiding of emotions (Connell 1997). In the context of theology and Christian mission, religion provides additional resources in the process of naturalising gender identity. Therefore, it is important that gender is recognised as a social construct (Connell 1997; Laurie et al. 1999).

It is also important to acknowledge that there has been concerted effort to generate scholarship, which responds to both feminine and masculine gender constructions, contrary to gender scholarship that initially focused primarily on women's experiences. For example, Connell's (1997) systematic research on 'hegemonic masculinity emphasised femininity' analysed both constructions, demonstrating how 'hegemonic masculinity' is oriented towards accommodating the interests of men - which essentially undergirds traditional patriarchal structures in African communities. Concurring with these observations, Kimmel (2002) rightly observed:

[T] he 'invisibility' of masculinity in discussions of [gender] has political dimensions. The processes that confer privilege on one group and not another group are often invisible to those upon whom that privilege is conferred. Thus, not having to think about race is one of the luxuries of being white, just as not having to think about gender is one of the 'patriarchal dividends' of gender inequality. (p. 18)

Attending to new complexities emerging for the mission of the church within the context of gender and migration will also require transformation of theological education in Africaand contextualising theological education in ways that approach theology through missional hermeneutics (Hendriks 2012)or considering the reformed identity and mission from the margins (Hewitt 2017). As Barrett et al. (2004:159) also observed, when the church is missional, it approaches encounters between God and human culture in transformative ways. Such encounters are at the centre of the migration experience and this underscores the missional role of the church as it provides a niche that connects God's purpose with humanity and all of creation (Hendriks 2004:21).

\section{The lived experiences of Ruth ${ }^{1}-$ Adolescent survival strategies for a young female migrant}

In my previous research, ${ }^{2}$ I reflected on the experiences of Ruth, a 19-year-old female migrant who was born to 1.Not her real name.

2.Data collected for PhD study: When the people move, 2015 
Ghanaian parents in the Ivory Coast and later migrated with them to South Africa at the age of 5 years. At the time of interviews, Ruth had just turned 19 years but still had no South African identity documents as she was refused the right to residency because her parents had not included her in their asylum papers. Naomi, Ruth's mother, had watched her daughter struggle to progress with school as she also struggled to find employment in Johannesburg:

$[I]$ n Ghana she helped women who gave birth ... the hospitals in Ghana are not so, ... the ambulance doesn't even come so you need a woman who you know if I'm giving birth she's gonna be there to help and yaaah she was that type of women who would help others ...she got paid and that's how she lived so that's the work my mum did in Ghana but here we not doing anything .... (Ruth, Yeoville, 27 April 2015)

Ruth recalled what her mother did to earn a living in Ghana and was frustrated that they both had nothing to do in South Africa, and consequently their family of six (four siblings and two parents) had to depend on their father whose income as a part time driver was not stable. Since 2010, Ruth and Naomi made several visits to the Home Affairs Offices in Pretoria and Johannesburg and they have been told by the Home affairs official that Ruth should return to Ivory Coast or Ghana. During the interview Ruth explained how she has persistently challenged their views and explained to them that she does not remember anyone in Ghana because her parents raised her in Ivory Coast and Johannesburg. She explained that although her family is West African, she considers herself to be South African and she looks to her local church as a way to mediate these complexities, because for her if you are in the church (Ruth, Interview Transcript, 2015):

[Y]ou actually feel at home and I've been in the church for the whole time that I've been in South Africa ... 15 years in the church and I don't regret any single moment being part of the church or being part of the youth or even being part of the Sunday school, everything is just cool here. (p. 8)

In one of my recent publications I employed a case study (Mpofu 2020c) to demonstrate the impact of changing cultural landscapes for migrant adolescents' identity as reflected on their agency in navigating new cultural contexts by developing and adapting to new lifestyles through components of cultural capital, namely, skills, competency, new personal qualities, fashion, hairstyling practices, language/accents as means for survival strategies and exploring host communities. Ruth resembled these qualities and contrary to her warmly experiences within the church community [where she felt 'at home'], Ruth explained how she has experienced hostility in her dealings with immigration officials [and the rest of intolerantSouth African communities]. Despite her circumstances Ruth persistently challenged prejudice against foreign African migrants and, at some point, expressed her frustration as she exclaimed:

[T] his is where I live, this is where I breathe, this is where I eat and sleep - where do they want me to go ... (Ruth, Yeoville, 27 April 2015)
The given quotation emerged from an interview conducted with Ruth in 2015 at Yeoville, Johannesburg, in one of the Reformed churches. Given that Ruth told the Home Affairs officials that she does not remember anyone in Ghana because her parents raised her in Ivory Coast before migrating to South Africa and settling in Johannesburg whilst she was only 5 years, it was frustrating for her to be told that they should go back to Ghana and so she exclaimed 'this is where I live, this is where I breathe, this is where I eat and sleep'. In the following sections, this article unpacks and interrogates this statement to highlight how one adolescent migrant embody the radical doctrine of hope as lived reality expressed through a resilient theology of survival sustained by developing and adapting to new lifestyles through cultural capital, skills, competency, new personal qualities, fashion, hairstyling practices, language/accents as means for survival strategies in the face of hostility.

Despite her experiences as a midwife, Ruth's mother can no longer make a living by helping other women as she did in Ghana. Migration did not just introduce her to a new community, but she also experienced changes in family income. In South Africa, her (Ruth's mom) agency is diminished as she and her family are also exposed to xenophobia and language barriers in attempts to get on with finding employment, decent accommodation and education. This presents a gendered dimension of the experience of migration as reflected in the research conducted by Sigworth, Ngwane and Pino (2008:33), who concluded that challenges experienced by migrants are not just poor service delivery and competition for resources, but migrant women also have to deal with the effects of long-term, recent and compounded trauma triggered by their experiences (Sigworth et al. 2008:33). As Ruth lamented (Ruth, Interview Transcript, 2015):

... [F]or me it's a very big disadvantage, and it really hurts my feelings whenever I think about it because number one South African women are not seen to be ... very competitive ... I'm a female just like those South African females even if I work hard I may not be accepted as much as a man would be accepted into a company.... (p. 9)

Ruth confirmed that she feels 'disadvantaged' being a female migrant given that most South African women struggle to be recognised in the professional field, and she is not only a woman, but also a foreigner without formal documents. Ruth later articulated her frustration in a profoundly revealing way as it inspired this article:

[S]outh Africa it's still a good place to be in and I really enjoy being here ... its actually my life now ... this is where I live, this is where I breathe, this is where I eat and sleep, so if I was actually supposed to go back to Ghana I don't think I would be able to survive. (Ruth, Yeoville, 27 April 2015)

\section{This is where I live}

Under these circumstances, articulations such as these generate and sustain hope for survival and reinforce the resistance to rejection or hostility. This stance resembles that taken by 
Tambu (Dangarembga 2004) in her colonial context as she fought patriarchal and colonial injustices. Both young women were challenging life-denying practices, which are a disadvantage for women. Whilst the two young women expressed these statements in different socio-economic and historical settings, there is a sense in which they both engage in a struggle of 'asserting' themselves and 'question things' around them, as they refuse 'to be brainwashed' through discourses, which counter the dominant narratives on their experiences. Unlike Tambu, Ruth does not have to go to a mission school to overcome her struggles, she draws from her very struggles for survival and coping strategies, which emerge as doctrines of resistance, as we demonstrate in the following (Ruth, Interview Transcript, 2015):

[I] didn't know anything about permit ... until last year when I had to become independent, I'm in Matric now I have to do things on my own, register to Varsities and all ... that's when my parents sat me down and told me that $u$ know what your paper they...I don't think they would ... print it for you because it has been upheld and I was really upset.... (p. 2)

Ruth discovered that she was not formally a South African resident when her parents 'sat' her down and told her that her asylum permit was withheld. In a sense, she is one of the stateless children raised by her parents in the diaspora. Residency is a major challenge for most migrants and Christian or faith communities sometimes provide a sense of belonging to people with such situations. As Landau (2009) observed:

$[R]$ eligion often serves to stabilise and bind communities, simultaneously defining communities by providing avenues of incorporation and mechanisms of exclusion. Its ability to promote cohesion and resistance often becomes most tested and visible in the face of unbelieving or differently believing new arrivals ... In as much as religion serves to mark and define other forms of identity, it too plays a critical role in these interactions. (p. 5)

Ruth was fortunate to be within a religious community in the congregation where she belongs. However, her identity and prospects of engaging religion as an avenue of incorporation are hindered by the absence of formal documents. In addition, her age and gender could easily serve as mechanisms of exclusion when she engages South African communities in life-sustaining activities such as higher education and employment. To be young, female and 'undocumented' complicates a potentially productive future for young migrants. However, like Tambu in Dangarembga's (2004) novel, Ruth has radically lived above these complications and pursued other avenues to survive, as she hoped that her young sister will not be faced with a similar situation when she has to apply for admission at the university (Ruth, Interview Transcript, 2015):

[S]o that just complicates my whole life and I hope that by the time my little sister is done with school she's gonna have a permit straight away because for some of us ... the only thing I'm able to do at the moment is take part in modelling um performing and dancing. (p. 4)

To live is to exist, in a particular space and time. Taking up modelling and performing dances is her new way of asserting herself in the face of rejection by those who should recognise all who live within the South African borders. When she declares that she lives, eats and sleeps in Johannesburg, it is an act of resistance to any form of threat to her life. It is defiance and a challenge to the dominant paradigms on citizenship and nationality and raises deep questions aboutbelongingness, space and identity. This experience of migration from a female perspective demonstrates not only resistance and resilience, but also paints a picture of a gendered migration experience characterised by a life on the margins of society. As a female migrant, Ruth's struggle reflects a doubledimension of the lived experiences of migrants in Johannesburg as they have to navigate both challenges emanating from their gender and those related to 'otherness' as foreigners. Such experiences provide a fertile breeding ground for what Williams refers to as 'doctrines of resistance'.

\section{This is where I breathe}

Ruth, Interview Transcript (2015):

[S]outh Africa it's still a good place to be in and I really enjoy being here ... its actually my life now ... this is where I live, this I where I breathe, this is where I eat and sleep, so if I was actually supposed to go back to Ghana I don't think I would be able to survive. (p. 2)

Denying Ruth the right to residency is denying her the right to live or breathe. To have a life means one can breathe. In the Bible the Spirit of God or his breath is presented through the Hebrew word Ruach [Spirit], which appears in the prophetic literature as a metaphor describing the experience and agency of God in Jewish history (Cruz 2007). Another literal meaning of Ruach is to breathe, which derives from the wind or moving air and the depth of personhood, the actual 'who' of a person. Therefore, Ruach (the moving Spirit of God)is a metaphor,which captures the identity of God's personality, as communicated through the depths of the human person. In human psyche, the heart is a place where God's Spirit moves and touches us as God transforms humanity into his likeness. Understood from the Jewish tradition, the 'who' of God transforms the 'who' of the Jewish people to connect them with God's heart to represent God in the communities where they live. For Ruth, to breathe and find South Africa to be 'a good place' to live in means that she is not just alive, but she is also an affirmation of God's presence as reflected in her agency in dealing with the experiences that she has to endure. This biblical understanding resonates with Paul's approach to God and Holy Spirit in 1 Corinthians 2:10-16 (New International Version [NIV]).

\footnotetext{
${ }^{10}$ these are the things God has revealed to us by his Spirit. The Spirit searches all things, even the deep things of God. ${ }^{11}$ For who knows a person's thoughts except their own spirit within them? In the same way no one knows the thoughts of God except the Spirit of God. ${ }^{12}$ What we have received is not the spirit of the world, but the Spirit who is from God, so that we may understand what God has freely given us.
}

For Paul, the Spirit of God is able to transform the human spirit in ways that draw humanity closer to God through all 
human encounters in the world. Therefore, transformation requires human agency so that the Holy Spirit turns lives around, the same way Saul and others were converted or thrown into the furnace where we are refined like gold as did Shadrach Meshech and Abednego. ${ }^{3}$ Or the Spirit may be as gentle as running water that cleanses and purifies on its way. As the WCC also acknowledges (ed. Keum 2013):

[G]od Empowers the Church in Mission through Christ in the Holy Spirit, God indwells the church, empowering and energizing its members. Thus mission becomes for Christians an urgent inner compulsion (1 Cor 9:16) and even a test and criterion for authentic life in Christ, rooted in the profound demands of Christ's love, to invite others to share in the fullness of life Jesus came to bring. (p. 33)

The WCCs understands the Mission of the Church to be that of (ed. Keum 2013):

$[G]$ od's Spirit - ru'ach - [who] moved over the waters at the beginning (Gn 1:2), being the source of life and breath of humankind (Gn 2:7). [Who] In the Hebrew Bible ... led the people of God - inspiring wisdom (Pr 8), empowering prophecy (Is 61:1), stirring life. (p. 15)

For Ruth, the radical nature of Ruach who 'stirs life' is revealed in her ability to create a world of possibilities and dreams through her modelling career that she has developed within a context of hostility. Denying Ruth the right to be in South Africa is to fail to recognise the presence and agency of God in her, but this has not hindered her from pursuing 'what God has freely given us'. Denying her some form of dignity and recognition also amounts to counting her amongst the dead, so she must remind those who would dare to listen that in fact she is still alive and can breathe. Even the dead do have space and they are counted amongst the dead where they have grave or burial registration numbers. Therefore, her radical exclamations demand that she should be recognised and counted amongst the living -amongst whom the Spirit of God dwells. This profound sense of belonging demonstrates resistance, resilience and creativity in a struggle against regimes of migration, which frame African migrants as undesired beings who pose a threat to South African society and calls for prophetic Christian social practice within the context of migrant women's experiences in South Africa.

\section{This is where I eat and sleep}

\section{Ruth, Interview Transcript (2015):}

$[Y]$ es, food that everybody else can eat. An African restaurant but then it had to close down because we kept getting robed and fridges were stolen and there were break ins so my mum had to quit the job [be]cause she was losing more money ... she's been at home for two years....(p. 7)

Given their struggles with identity documents in South Africa, Ruth and her family have struggled to get decent jobs. To eat and sleep well means there is decent food and accommodation. To have food and decent accommodation requires work. In order to be employed in South Africa one needs to have an identity document. Despite, trying to run her own business by operating a restaurant serving African dishes, Ruth's mother had to close down the shop after several robberies. Despite experiencing all these challenges, Ruth can exclaim, 'this is where I eat and sleep'. Read through the lens of Dangarembga's narrative, this is a revolutionary challenge to the oppressive system, which refuses to recognise her family by providing them with support to get employment. By stating that it is here in South Africa where she eats and sleeps, Ruth reminds us that where you can eat and sleep is a place to call home. Depending on individual experiences and circumstances, there are different concepts of understanding home, and for her the fact that she has lived, breathed, eaten and slept in Johannesburg for the past 14 years simply means that she is at home. This is the reason she has taken up modelling and dancing so that she will continue to support her family. Ruth indicated that there were times when the church provided food for her family but this was for a limited period. As a result, she took advantage of being in the church and made contacts with people who introduced her to promoters looking for young female models.

\section{Doctrines of resistance}

Although there are migrants and refugees who are pushed by their desperate circumstances to 'exchange access to loved ones' bodies for social and food security' as Tushima (2018) observed through interrogating Genesis 12:10-13:2. The survival strategies employed by Ruth provide evidence that some migrants engage in deep spirituality of resistance. Another example is Williams' (1993) reflections on how black American women struggled for survival in search of quality of life as she uncoveredlife-affirming practices throughlifegiving narratives on the experiences of black American women in a 'womanist God-talk'. She referred to these life flourishing practices and discourses as 'doctrines of resistance'. She articulated a gender sensitive theology that recognises the agency of women and drew attention to how women survive the threats to their well-being. Examined through this framework, the profound statement of Ruth, 'this is where I live, this is where I breathe, this is where I eat and sleep', demonstrates her resistance to life-denying practices in a simple but practical way. It is a reflection of resilience and creativity of women in their struggles albeit within the context of statelessness and migration. Historically, women always had means and ways to cope with colonial and patriarchal oppressive practices. According to Williams, (Cruz 2010:188) resistance has continued to be a part of the black people's lives even beyond slavery. For example, in applying this concept within the context of migration, she cites domestic workers' resistance strategies against exploitation by their employers, which include refusal to stay overnight at employers' homes, ensuring frequent break times during the day and even checking in at their own makeshift homes, taking foods and other essentials from employers as things which rightfully 
belonged to them, challenging entering through the back or kitchen doorsand challenging disciplinary actions taken by their employers. ${ }^{4}$ Williams refers to these practices as 'doctrines of resistance'. For her, black women's survival strategies display their skills of creativity through three forms of art: the art of encounter (which involves resistance and endurance), the art of cunning (which draws from imagination) and the art of care (which is manifested in their commitment and charity towards one another and families back in their home countries) and an art of connecting (through which they network).

Unlike Williams, Ruth embodies the radical doctrine of resistance as lived reality expressed through her body and thus requiring a theology not just of solidarity and mobilisation of migrants, but pastoral theology of care and sustenance for the migrant body in everyday life. Taking seriously the agency of women migrants such as Ruth who cross borders without visas and sometimes passports to join their families or look for study and employment opportunities will require appreciating the gendered nature of migration and survival strategies to employ women to ensure that migrants are not bundled together in the category of criminals. Williams' motif of doctrines of resistance helps us to appreciate that African migrants display creativity in their pursuance of quality of life. In her themes on survival strategies and how women develop and use such lifeaffirming strategies to govern their lives according to their mother's counsel (what they have historically been taught), Williams chronicles how during slavery the mothers passed on the 'doctrine of resistance' embodied in the narratives: 'Fight and if you can't fight, kick: if you can't kick then bite'. Whereas Williams identifies four forms of resistance - the art of encounter, the art of being cunning, the art of care and the art of connecting - Ruth displays embodied resistance, which emerges as an engendered theology of migration rooted in her creativity of asserting herself, refusing to be brainwashed and refusing to be determined by the circumstances around herself.

\section{Conclusion}

This article highlighted survival strategies for young migrants and demonstrated how the changing global socioeconomic landscapes and povertyimpact migrant communities in ways that present opportunities to explore alternative missional paradigms and theologies that address conditions of deprivation. Although not a representative sample of migrant experience, this analysis also highlighted how some migrant women use situations of deprivation to promote socio-economic transformation through resistance, whichembodies radical hope as lived reality expressed through her body and thus it requires a theology not just of solidarity and mobilisation of migrants, but a theology of care and sustenance for the migrant body in everyday life. Taking seriously the agency of young women migrants such

4.Dolores Janiewski, 'Sisters Under the Skins: Southern Working Women, 1880-1950"' in Hine, Black Women in the United States History, vol. 3, pp. 737-738 cited in Williams, Sisters in the Wilderness, p. 128. as Ruth who crossborders sometimes without visas and passports to join their families under life-threatening experiences as they search for study and employment opportunities will require appreciating the gendered nature of migration. It is important that policy makers, security agencies and governments understand these life-affirming survival strategies employed by displaced and mobile women to ensure that migrants and refugees are not bundled together with criminals. Appreciating their agency and the complexity of circumstances surrounding vulnerability of migrant women and young girls is critical and demands that we pay attention to their needs in line with the United Nations (UN) Sustainable Development Goals (SDGs).

\section{Acknowledgements}

The author would like to acknowledge the generous contributions of members of the Uniting Presbyterian Church in Southern Africa (UPCSA) congregations, which took part in the initial focus group discussions.

\section{Competing interests}

The author solemnly declares that he has no financial or personal relationships which may have inappropriately influenced him in writing this article.

\section{Author's contributions}

The author contributed to this work individually although some sections of the article were guided by the supervisor during the post-doctoral fellowship at the University of KwaZulu Natal (UKZN) School of Religion, Classics and Philosophy.

\section{Ethical considerations}

University of Pretoria, Faculty of Theology and Religion, Research Committee - T027/20

Whilst ethical clearance was sought to conduct research on COVID-19, this article did not involve data that needed ethical procedures as it relied on literature review and media statements.

\section{Funding information}

This research received no specific grant from any funding agency in the public, commercial or not-for-profit sectors.

\section{Data availability}

Data sharing is not applicable to this article as no new data were created or analysed in this study.

\section{Disclaimer}

The views and opinions expressed in this article are those of the author and do not necessarily reflect the official policy or position of any affiliated agency of the author. 


\section{References}

Adogame, A., 2010, 'Pentecostal and charismatic movements in a global perspective', in B.S. Turner (ed.), The New Blackwell companion to the sociology of religion pp. 498-518, Wiley-Blackwell, Oxford.

Adogame, A. \& Spikard, J., 2010, Religion crossing boundaries: Transnational religious and social dynamics in Africa and the new African diaspora, Brill, Leiden.

Agbiji, O.M. \& Swart, I., 2015, 'Religion and social transformation in Africa: A critical and appreciative perspective', Scriptura 114(1), 1-20, viewed 27 January 2021
from http://www.scielo.org.za/scielo.php?script=sci_arttext\&pid=S2305-445X20 from http://www.scielo.org.za/s.

Barret, L.Y., Guder, D.L., Hobbs, W.C., Hunsberger, G.R., Stutzaman, L.L. \& Van Koten, J. (eds.), 2004, Treasure in clay jars: Patterns in missional faithfulness, Eerdmans, Grand Rapids, MI.

Butler, J.P., 1990, Gender trouble: Feminism and the subversion of identity, Routledge, New York, NY.

Connell, W., 1997, 'Hegemonic masculinity and emphasized femininity', in L. Richardson, V. Taylor \& N. Whittier (eds.), Feminist frontiers IV, pp. 22-25, McGraw-Hill, New York, NY.

Cruz G.T., 2007, 'One bread, one body, one people: The challenges of migration to theological reflection', CTSA Proceedings 62(1), 208-228, viewed 27 January 2021, from https://ejournals.bc.edu/index.php/ctsa/article/view/4906.

Cruz, G.T., 2010, An intercultural theology of migration: Pilgrims in the wilderness, Brill, Leiden.

Dangarembga, T., 2004, Nervous conditions, Clarke Publishing, Edinburgh.

Erasmus, J.C., 2005, 'Religion and social transformation: A case study from South Africa', Transformation 22(3), 139-148. https://doi.org/10.1177/ 026537880502200303

Groody, G.D. \& Campesse, G. (eds.), 2008, A promised land, a perilous journey: Theological perspectives on migration, University of Notre Dame Press, Notre Dame, IN.

Hagan, J. \& Ebaugh, H.R., 2003, 'Calling upon the sacred: Migrants' use of religion in the migration process', International Migration Review 37(4), 1145-1162. https:// doi.org/10.1111/j.1747-7379.2003.tb00173.x

Hendriks, H.J., 2004, Studying congregations in Africa, Lux Verbi, Cape Town.

Hendriks, H.J., 2012, 'Contextualising theological education in Africa by doing theology in a missional hermeneutic', Koers 77(2), 1-8. https://doi.org/10.4102/koers.v77i2.56

Henley, J., 2020, Female-led countries handled coronavirus better, study suggests, viewed 27 January 2021, from https://www.theguardian.com/world/2020/ aug/18/female-led-countries-handled-coronavirus-better-study-jacinda-ardernangela-merkel.

Hewitt, R., 2017, 'Reformed identity and mission from the margins', STJ Stellenbosch Theological Journal 3(2), 99-122. https://doi.org/10.17570/stj.2017.v3n2.a04

Hooks, B., 2004, We real cool: Black men and masculinity, Routledge, New York, NY.

International Association of Mission Studies (IAMS), 2012, Listeners' report: Meeting of the International association for mission studies, viewed 11 March 2021, from https://missionstudies.org/wp-content/uploads/2009/01/listeners-report.pdf.

Keum, J. (ed.), 2013, Together towards life: Mission and Evangelism in changing landscapes, World Council of Churches (WCC), Geneva, viewed 11 March 2021, from https://www.oikoumene.org/sites/default/files/File/Together $\% 20$ towards\%20Life_Mission\%20and\%20Evangelism.pdf.

Kimmel, M., 2002, 'Foreword', in F. Cleaver (ed.), Masculinities matter! Men, gender and development, pp. xi-xiv, Zed Books, London.

Kostakopoulou, D., 2003, 'Why naturalisation?', Perspectives on European politics and society 4(1), 85-115. https://doi.org/10.1080/15705850308438854

Landau, L., 2009, 'Living within and beyond Johannesburg: Exclusion, religion, and emerging forms of being', African Studies 68(2), 197-214. https://doi. org/10.1080/00020180903109581
Laurie, D.C., Holloway, S. \& Smith, F., 1999, Geographies of new femininities, Longman, London.

Levitt, P., 2007, God needs no passport, The New Press, New York, NY.

Messner, A., 1992, Power at play, Beacon Press, Boston, MA.

Mitchem, V.S., 2002, Introducing womanist theology, Orbis Books, Maryknoll, NY.

Mpofu, B., 2015, 'When the people move, the Church moves: A critical exploration of the interface between migration and theology through a missiological study of selected congregations within the Uniting Presbyterian Church of Southern Africa in Johannesburg', Unpublished PhD thesis, UKZN School of Classics Religion and in Johannes
Philosophy.

Mpofu, B., 2018a, 'Church as Hostile, Host or home: Perspectives on the experiences of Africa migrants in South Africa', Alternation Journal 22(1), 103-118. https://doi. org/10.29086/2519-5476/2018/sp22a6

Mpofu, B., 2018b, 'Economic inclusion: A paradigm shift from the radical economic transformation (RET) in the context of xenophobia in South Africa', Advances in Politics and Economic 1(2), 126-135. https://doi.org/10.22158/ape.v1n2p126

Mpofu, B., 2019a, 'Migration, xenophobia and resistance to xenophobia and socioeconomic exclusion in the aftermath of South African Rainbowism', Alternation 26(1), 153-173. https://doi.org/10.29086/2519-5476/2019/v26n1a7

Mpofu, B., 2019b, 'Theologies of belonging and emerging transnational identities in Southern Africa', in A. Bieler, I. Karle, H. Kim-Cragg \& I. Nord (eds.), Religion and migration: Negotiating hospitality, agency and vulnerability, pp. 79-92, Evangelische Verlagsanstalt, Berlin.

Mpofu, B., 2020a, “"It is now in your hands": South Africa's dilemma for religion and governance in the changing COVID-19 context', HTS Teologiese Studies/ Theological Studies 76(1), a6183. https://doi.org/10.4102/hts.v76i1.6183

Mpofu, B., 2020b, 'Mission on the margins: A proposal for an alternative missional paradigm in the wake of COVID-19', HTS Teologiese Studies/Theological Studies 76(3), a6149. https://doi.org/10.4102/hts.v76i3.6149

Mpofu, B., 2020c, 'Navigating changing cultural landscapes: A quest for identity and belonging among migrant children and youth in Pietermaritzburg, South Africa', Alternation Special Edition 34(1), n.p.

Müller, J.C., 2011, 'Post foundational practical theology for a time of transition', HTS Teologiese Studies/Theological Studies 67(1), a837, 5 pages. https://doi. org/10.4102/hts.v67i1.837

Parekh, B.C., 2000, Rethinking multiculturalism: Cultural diversity and political theory, Harvard University Press, Cambridge.

Pillay, J., 2017, 'The church as a transformation and change agent', HTS Teologiese Studies/Theological Studies 73(3), 1-12. https://doi.org/10.4102/hts.v73i3.4352

Rivera, P., 2012, 'Xenophilia or xenophobia: Toward a theology of migration', in E. Padila \& P. Phan (eds.), Contemporary issues of migration and theology pp. 31-51, Palgrave Macmillan, London.

Ruth (pseudonym), 2015, Interview: 27 April 2015, Yeoville Presbyterian Church, Yeoville Johanneburg.

Sigworth, R., Ngwane, C. \& Pino, A., 2008, The gendered nature of xenophobia in South Africa, Centre for Study of Violence and Reconciliation (CSVR), Braamfontein.

Smith, S., 2014, 'Limitations to equality: Gender stereotypes and social change', Society and Migration, viewed 20 January 2021, from https://www.ippr.org/ juncture/limitations-to-equality-gender-stereotypes-and-social-change.

Tushima, C.T.A., 2018, 'Exchange of wife for social and food security: A famine refugee's strategy for survival (Gn 12:10-13:2)', HTS Teologiese Studies/ Theological Studies 74(1), a4769. https://doi.org/10.4102/hts.v74i1.4769

United Nations (UN), Transforming our world: The 2030 agenda for sustainable development, viewed 27 January 2021, from https://sustainabledevelopment. un.org/content/documents/21252030\%20Agenda $\% 20$ for $\% 20$ Sustainable $\% 20$ Development\%20web.pdf.

Williams, D.S., 1993, Sisters in the wilderness: The challenge of womanist god-talk, Orbis Books, Maryknoll, NY. 